\title{
Muslim Society Trondheim: A Local History
}

\author{
Ulrika Mårtensson \& Eli-Anne Vongraven Eriksen
}

\begin{abstract}
The article describes and analyzes the founding and development of Muslim Society Trondheim (MST), a jâmi ' mosque and Islamic organization in Norway's third largest city, Trondheim. The aim is to explore the significance for integration policy on 'active citizenship' and two-way accommodation between majority and minority of MST's dialogues with the church and public institutions, with reference to Casanova's concept 'de-privatized public religion' and Roy's 'churchification of Islam'. Main findings are that the dialogue with the church was the one which achieved the best results in terms of two-way accommodation; that MST's dialogues have contributed towards the city's Muslims claiming their civil and human rights; and that because this does represent a 'churchification' of Islam, it does not make MST a case of 'de-privatized public Islam' in Casanova's sense.
\end{abstract}

One has to face one's own prejudices sometimes. One thinks that a politician is only concerned with this and that, or someone who works in that place [has to be like this]; so all this about direct contact [between Islamic organizations and public authorities] and getting things more regularly organized is very important and challenging, but [the challenge] must be taken. For it can give huge rewards both for our community, the Muslims, and also for the municipality and the state institutions because the trust that a mosque has as a point of connection for all these cultures and all the different people is very significant. So then it is important to be a bit careful and not abuse it, and use it wisely. (member of Muslim Society Trondheim, February 2010). 
Trondheim is Norway's third largest city with a population of 171,000 , located in the middle of the country on a wide, beautiful fjord. The city was founded in 997 . Between 1030 and 1217 it was the royal capital and played a significant role in the foundation of Norway as a Christian nation, hosting the national sanctuary, the Nidaros Cathedral. According to medieval lore, the cathedral was erected on the burial site of the national saint, Olav the Holy, hailed as the first king to introduce Christianity to pagan Norway. Olav was duly martyred in the Battle of Stiklestad on 29 July 1030. Since around 1300, the Nidaros Cathedral has been a pilgrimage destination. Today Trondheim celebrates St Olav's martyrdom annually on 28 and 29 July. A theatrical re-enactment of the battle is staged at the historical battlefield, not unlike the Shiite ta 'ziya performance of Imam Husayn's martyrdom in the Battle of Karbala in 680. While the Norwegian actors do not let their own blood, as Shiite penitents do, they sing a hymn about King Olav's blood and its redeeming power. Trondheim thus hosts the founding myths and memories related to Norway's national identity.

Today all faith communities participate in the city's annual celebration of St Olav. In line with the arguments developed in the Introduction to this special issue, their participation symbolizes how Norway's traditional Christian identity is changing into a multi-religious and simultaneously more secular national identity. Yet the Church of Norway continues to play an important role as the midwife of this new national identity, for instance, by assisting Muslims in their dealings with 'public Norway'. Trondheim's first mosque organization, Muslim Society Trondheim (MST), was established in 1987 by Muslim students at what is today The Norwegian University of Science and Technology (NTNU). This article describes how MST, through interactions with the Church and with public institutions, has become the public representative of Trondheim's Muslims, and analyses to what extent MST's public activities correspond to the concepts of 'de-privatized public religion' (Casanova 1994) and 'churchification of Islam’ (Roy 2004; 2009). 


\section{Civic Integration: Dialogue or Monologue?}

As mentioned in the Introduction to this volume, EU integration policy proposes intercultural dialogue as the way to achieve two-way accommodation between 'majority' and 'minority', within the normative civic framework of human rights and liberal democratic values and procedures. Recent studies highlight that this normative framework risks turning dialogue into more of a one-way communication from majority to minority than a real dialogue. Exploring Germany's official forum for intercultural dialogue with Islam, Schirin Amir-Moazami finds that power-relations in the German context are heavily skewed since the non-Muslims - including the evangelical churchidentify with and represent the state's integration objective in the dialogue. Muslims are thus forced to address pre-selected issues and it is taken for granted that Muslims are more in need of guidance than the majority representatives (Amir-Moazami 2010; 2011; Dornhof 2012). ${ }^{1}$ Similarly in a Swedish Christian-Muslim dialogue group initiated by the Church of Sweden, one of the Muslim participants remarked that the dialogue themes reflected Christian 'majority' interests and beliefs and reduced the specificity of Islam by insisting on Christian categories. The Muslim ban on alcohol or belief in paradise and hell were not possible to discuss, since the dialogue focused on what the Church of Sweden considered to be 'issues of common concern', i.e. human rights, peace efforts relative to international conflicts, gender, etc. (Roald 2002:91-2).

Anne Hege Grung has participated in Muslim-Christian dialogue in Norway since the 1990s. Reflecting on Amir-Moazami (2010; 2011) and Roald (2002) Grung identifies the approach adopted by dialogue practitioner Oddbjørn Leirvik as a way to raise awareness of the risks that pertain to discrepancies in power. All religions need to be continuously reinterpreted, even contemporary 'official Christianity', and all religions contain multiple and sometimes conflicting interpretations. In dialogue settings the meeting with 'the other' shall be what generates new 'internal' interpretations, for both

\footnotetext{
${ }^{1}$ See Verkaaik (2010) for analysis of how Dutch citizenship rituals express the notion that the 'ethnic' Dutch represent the civic value of democracy which immigrants and their children are assumed to learn through the new naturalization programme.
} 
parties. Leirvik also follows a method adopted by a UK dialogue group, Scriptural Reasoning, where participants read and interpret each other's scriptures, a method that can level the religions at least within the dialogue group and brings out what is specific to each one of them. Leirvik too sees human rights as a key issue for interpretations because they challenge all religions and grant minorities rights in relation to the majority. The purpose of interfaith dialogue should thus be to arrive at a platform for joint action that criticizes inequalities in power with reference to human rights (Grung 2011:31; cf. Leirvik 2007; Leirvik 2011a:346-8;).

European and Nordic churches are involved in the integration of Muslims not only through interfaith dialogue but also through organizational matters. Olivier Roy's concept of the 'churchification' of Islam signifies that states press for Muslims to organize in ways that differ from Muslim majority countries but resemble the ways in which churches and religions are traditionally organized in Europe. In addition imams are increasingly required to perform public services corresponding to the churches' chaplaincy institution (Roy 2009: 189-90). However, requirements come not only from the top (the state), but also from below (the members of mosque organizations). Many European Muslims are immigrants. Since many frequent the mosques to meet with fellow countrymen and co-religionists, mosque leaders need to address numerous matters that face new immigrants and concern public authorities and services. This circumstance substantially widens the range of issues that an imam, for instance, has to deal with in Europe compared with majority Muslim countries (Roy 2004: 210-11; cf. Cesari 2004: 127-31; Vogt 2008: 84-9, 96-9).

In this article the broader question that this special issue raises, concerning the nature of 'public Islam' in Nordic contexts, is here referred to in terms of both Roy's 'churchification' and Casanova's 'de-privatized public religion'. According to Casanova, 'de-privatized public Islam' would refer to Muslims struggling to 
define and set the modern boundaries between the private and public spheres, between system and life-world, between legality and morality, between individual and society, between family, civil society, and state, between nations, states, civilizations, and the world system. (Casanova 1994:6).

'Churchification' on the other hand implies that Nordic Muslims work within the boundaries set by the Nordic model for organizing religion in civil society and with reference to all the demands that 'integration' places on Muslim religious leaders and laymen. The specific aim in this article is thus to explore the significance for 'active citizenship' and two-way accommodation between majority and minority of MST's dialogues with the church and public institutions, with reference to Casanova's 'deprivatized public religion' and Roy's 'churchification of Islam'.

\section{Norwegian National Dialogue}

The largest national Islamic 'umbrella organization' is the Islamic Council of Norway (Islamsk Råd Norge/IRN) which represents 41 of the approximately 130 Norwegian Muslim organizations, in total some 60,000 members. IRN's objectives are highly integration oriented, focusing on the formation of a Norwegian-Muslim identity and teaching Islam to Norwegian Muslims in a way that enables them both to practise Islam and to be active citizens; promotion of Muslims' rights through dialogue; problem solving between Muslims and the general public; and explaining Islam to the public so that Muslims are valued as an important resource for Norway (IRN 2010). One of the most 'civically active' of IRN's member organizations in Oslo is al-Rabita, a mosque affiliated with the Federation of Islamic Organizations in Europe (FIOE) and the Muslim Brotherhood (see Introduction to this special issue).

IRN represents Islam in the Contact Group, the interfaith dialogue between Islam and the Church of Norway that Oddbjørn Leirvik initiated in 1993 (IRN 2010; Leirvik in this volume). In 1996 the Contact Group was integrated into a new national framework for dialogue between all religions and 'life stance communities' in Norway (including the secular Humanists), the Council for Religious and Life Stance Communities (STL). 
STL has local branch organizations in the major cities, including Trondheim (STL 2010).

While the Contact Group includes doctrine, scripture and interpretation in its work, the issues of human rights, gender and conflict resolution have occupied a central place, as described by Grung (2011) and Leirvik (2011a; 2007). The Contact Group's public statements 'Declaration of Freedom of Religion' (Freedom 2007) and 'Joint Statement on Violence in the Family and Close Relationships' (Violence 2009) are significant both because of their content (see Leirvik, this volume) and their form. Their language emphasizes that freedom of religion and violence in close relations concerns Christians as much as Muslims. The approach contrasts sharply with Norwegian political debates which usually cast Muslims as the religious group that has a problem with genderrelated issues and human rights generally, and it signifies that the Church recognizes Muslims as religious equals. Thus, while the Church of Norway dominates in the sense that it insists on dialogue about such integration-related concerns as human rights and gender, it does not publicly act as if only Muslims are challenged by these issues, which appears to contrast with the findings from Germany (Amir-Moazami 2010; 2011). Another example is Norway's cartoon crises. In 2006 a right-wing Christian publisher decided to reprint the Danish cartoons of the Prophet Muhammad. In Norway, both the Church and the state under a Labour Party-led government publicly supported Muslims' right to peaceful protest against the offence caused by the cartoons (Leirvik 2011b). Neither the Church nor the state cast the majority as defending freedom of expression against restriction-minded Muslims, but emphasized the responsibility of all citizens to reflect on the ethical limits of freedoms and rights, and arranged for the publisher of the cartoons to apologize publicly to Norway's Muslims for offending their religious dignity (Mårtensson 2013). As we shall see, the approach where the Church backs Muslims in using civil and human rights to argue their cases in relation to the public prevails in Trondheim's interfaith dialogue as well. 


\section{Trondheim's Islamic Organizations}

Trondheim's Muslim population is mainly first-generation immigrants, represented by four Muslim organizations. Established in 1987 by students at Trondheim's technical university and with 1500 members (2011), Muslim Society Trondheim (MST) is the oldest and largest. The second largest is Trondheim Mevlana Cultural Organization, founded in 2003 and with 1062 members (2011) of Turkish and Kurdish origins who left MST to cultivate their specifically Turkish Islam. The third organization is Ahl O'Bait Centre. It was registered in 2002 and has 203 members (2011) who are Twelver Shiites from Iraq and Afghanistan. The fourth organization, Dar El Eman, was founded in 2011 and consists of former members of MST who formed a group around one of MST's imams who is of Somali background and has special expertise in hadith.

MST's members are from around 30 countries: Somalis, Arabs, Afghans and Indonesians are currently the largest groups. This multinational constitution makes MST unique in Norway:

In Oslo, as in most West-European capitals, mosques and Islamic centers are usually established on the basis of ethnicity, language and cultural backgrounds, nationality and religious affiliation. Mosques and Islamic centers organized on a pan-Islamic paradigm, for example the Muslim Society in the city of Trondheim, are the exception. The latter model reflects, according to its members, the concepts of tawhid and umma and expresses the diversity of Islam within its unity. (Naguib 2001:30-1).

MST is Trondheim's central jami', housed in a riverside warehouse building in the city centre. It is the only one of Trondheim's Islamic organizations that is a member of IRN. While individual members of the other Islamic organizations have contacts with public institutions and participate in the national interfaith dialogue (STL), only MST is engaged in official dialogue with the Church and negotiates with public institutions on behalf of Muslims' religious interests, an authority to which members of the other 
Islamic communities have said in conversations that they have no objections because of MST's ecumenical identity and status as the central jami ${ }^{\text {. }}$

This study of MST is based primarily on semi-structured interviews. From MST we interviewed three men and one woman with a long history in the organization and who have had leadership positions but who represent different positions regarding the organization's purpose and management. Given the limited scope of this study, these persons were selected because within MST they have the most experience of dialogue with the Church and other public institutions. The main limitation with this selection is that we could not study 'ordinary' members' views of the leaders' dialogue work. This will have to be explored in further studies. We have also had several other meetings with members of MST, including a public evaluation of the Church-MST dialogue (2003-11) on 2 April 2011. Finally, we have used official reports which document aspects of MST's institutional interactions. ${ }^{1}$ From the Church of Norway we interviewed one priest, a man who has been involved in the dialogue with MST since 2003. From the police we interviewed one man and one woman who have worked closely with MST. From the childcare authorities and the integration authority we interviewed one woman representative of each, and they were the ones who have actively collaborated with MST. We are indebted to all our interviewees for the time and thought they have given to our study.

\section{Muslim Society Trondheim: The Organization}

In Norway all religious organizations, including the Church, receive public funding on the basis of membership records. This overlaps with the Nordic civil society model

\footnotetext{
${ }^{1}$ These documents are: Det Muslimske Samfunnet i Trondheim (MST). Årsapport 2009 (Muslim Society Trondheim, Annual Report 2009); Forum for muslimsk-kristen dialog, Trondheim. Perspektiver fra samtalen 2005-2009 (Muslim-Christian Dialogue Forum, Trondheim. Perspectives from the conversation 2005-2009); Fra samtalen 2003-2005. Dialog mellom kristne og muslimer $i$ Trondheim (From the conversation 2003-2005. Dialogue between Christians and Muslims in Trondheim); Felles erklaring om trosfrihet 2007 (Declaration of Freedom of Religion 2007).
} 
where citizens represent their group interests to public authorities through publicly funded associations. In 2010 MST's income was around 1.1 million NOK, around 80\% of which is public funding. The organization is built around the general assembly; the Shura committee; the steering committee; and the imam office, reflecting a democratic division between judicial, legislative and executive functions, with the imam office serving as experts on Islam with responsibility for the Friday sermons and the correct teachings of Islam.

With regard to teachings, MST's bylaws contain an interesting paragraph, no. 2.1:

MST's aim shall be to serve the interests of Islam and the Muslim community in Trøndelag in such a way that the members are able to practise Islam as a perfect way of life. In all of its activities MST shall respect and abide by the country's laws, in so far as the latter do not conflict with Islam's spiritual principles. (MST Bylaws 2010; italics added).

In comparison, IRN, of which MST is member, does not mention potential conflicts between Norwegian laws and Islamic principles:

IRN shall be a voluntary, religious, democratic, and politically independent organization whose activities abide by Norway's laws. (IRN Bylaws 2006).

MST as an organization does not identify with any particular Islamic doctrine or agenda. Yet, MST's emphasis on active civic engagement stands out compared with the other local Islamic organizations and is of the same spirit as that evinced by the Muslim Brotherhood in Oslo (cf. Leirvik in this volume). MST's more ambitious objectives include:

[to c]onduct seminars on different subject-matters and courses in Islamic and Norwegian history, society and tradition, in Norwegian, English and Arabic, as well as provide mother-tongue teaching, for the sake of assisting MST's members 
to integrate in Norwegian society and be law-abiding citizens with supreme values and a high moral standing. (MST Bylaws 2010, par. 2.9).

The organization has been through a sequence of challenges related to generational and demographic changes among its members. In the beginning university students dominated, many of Pakistani and Turkish-Kurdish background. Some had high levels of education and wide networks. By 2010 the largest groups of members were of Somali and Arab backgrounds. Many were new immigrants and were not highly educated. The demographic change has involved a contestation of leadership, between academics, often with knowledge of Arabic and the Islamic scriptures, and members without academic degrees and often not Arabic speaking. The struggle involves contestation of both the meaning of Islamic principles and access to leadership functions. One member describes the situation through a personal interpretation of the Prophet:

We need everyone, from builders to craftsmen to academics, so, there was perhaps a bit of a tendency before that maybe there was a bit of an intellectual elite, who, in a way, wanted to be in charge, and there were many who reacted against that, because that is not from sunna and the Prophet (PBUH) who was himself a commoner, not a learned man, but a very wise man. So we must use that example in the best possible way, so that there won't be an intellectual elite of some sort, so that there will be many ways in which one can be a resource. (interview MST February 2010).

Tensions escalated into conflict. During 2009, MST went through three successive steering committees as members struggled to solve the dispute. The above-mentioned paragraph 2.1 of the bylaws was also drawn into the conflict, concerning the issue of marriage. Some members argued that the paragraph was introduced by members with good intentions but incomplete understanding of Islam and that members who now have higher Islamic education know that Islam obliges Muslims to abide by the law of the land. They can seek to change a law by democratic means but as long as it is in force they must abide by it, in line with Shaykh al-Azhar's fatwa concerning the French law 
against hijab in public schools, and the approach taken by the European Council of Fatwa and Research (interview MST November 2010). Concerning marriage, these members hold that MST's imams should not bless any marriage which is not registered in Norwegian civil law, which rules out polygamy, among other things. Other members believe that since Sharia is the sacred guidance for Muslims it must have priority on principle; hence, polygamy cannot be illegal although Sharia conditions for it are such that no one can actually fulfil them (interview MST November 2010).

Eventually the conflict over power and over Islamic principles grew so heated that MST members contacted the police and IRN to mediate, with good results (interview MST March 2010). In 2010 new bylaws were passed which stipulate that out of fifteen members in the Shura committee, there can be at most four from each nation (par. 7.2), and out of members members of the steering committee, there can be at most two from each nation (par. 8.2.2). These rules, which although contested were crucial for achieving unity between the different positions in the conflict, maintain MST's 'panIslamic' character and prevent national groups from dominating the organization. Paragraph 2.1 remains in force while the imam office ensures that MST's activities (including marriages) are in line with Norwegian law (interview MST November 2010).

\section{Interfaith and Intercultural Dialogues}

The conflict was not so bad that MST was unable to maintain dialogues initiated long before with the Church of Norway; Trondheim municipality; the childcare authorities; the integration authorities (IMDi); and the police. These will now be described in some detail. The significance of the selected dialogues to those involved should be understood also with reference to issues raised in the Introduction to this special issue but not treated specifically here, i.e. the negative attitudes towards Islam and Muslims that are communicated in the national mass media along with documented discrimination in the labour and housing markets (IMDi 2009), as well as varying degrees of non-acceptance of Muslim values and practices in schools, a public institution with which children and parents interact on a daily basis (Holm 2011; IMDi 2008; ISF 2009). 


\section{Forum for Muslim-Christian Dialogue}

The Forum for Muslim-Christian dialogue in Trondheim is a local branch of the national Contact Group. Officially established on 8 May 2003, it was initiated by the bishop of Nidaros in response to $9 / 11$ and security concerns over radicalized Muslim communities and public anti-Muslim sentiment. From 2003 to the present, six representatives from each religion have met six times per year. With minor changes, it has been the same group throughout (interview Church March 2010; dialogue meeting April 2011).

The aim of the dialogue is not to reach agreement but to understand 'the other' and 'the self' as it relates to 'the other'. The method consists in seven steps: to listen, take notes, reflect, check with the others, give and receive response, document and conclude, and it is applied in dialogue over themes which are mutually agreed upon (dialogue meeting April 2011; Samtalen 2003-2005; Forum 2010). The notorious cartoon crisis motivated three dialogue themes: 'Living together with respect for difference', 'Freedom of speech and blasphemy', and 'Apology and forgiveness'. MST's initial reaction to the cartoons was to prosecute for blasphemy, but after deliberations in the Forum they decided to align themselves with the national Contact Group's strategy to obtain a public apology from the publisher. In 2008 a local Trondheim cartoonist published a provocative cartoon, and members of MST felt sufficiently confident to use the same 'civic' procedure as with the 2006 cartoons to ask for a meeting with the publisher and convey their views (interviews, the Church and MST March 2010).

Trondheim's Forum has also addressed issues beyond the formal dialogue themes. The Muslim participants and many of MST's members had serious concerns with the municipal childcare authorities, especially regarding custody of children. In these cases the authorities placed Muslim children in non-Muslim foster homes at great distance from Trondheim. MST's members wanted Muslim foster families so that children in custody would be raised as Muslims; and that foster families should live nearby so that the family did not lose contact with their child. In 2005 the Forum, in cooperation with Trondheim municipality and the Ombudsman for children, initiated a conference on 
immigrants' experiences of the childcare authorities, since non-Muslim groups also experienced problems in communication with this particular authority. Contacts were thus established between the childcare authorities and MST, and a number of Muslim foster families have since been approved by the authorities and have received foster children. Relations suffered a setback, however, when the authorities placed a Muslim child with a lesbian non-Muslim couple. The Forum then responded collectively, expressing disappointment with the municipality's apparent reneging on its intention to accommodate minorities' values (interviews, the Church and MST March 2010).

At the national level, the childcare authorities are campaigning against female genital mutilation (FGM), which concerns Somali families in particular. In connection with the Forum's dialogue theme 'Respect for nature and preservation of the work of creation', Imam Abdinur Mohamed, who is of Somali background, wrote a treatise using classical fiqh and arguing that FGM is against Sharia because it lacks support in the Qur'an and in sound Prophetic hadiths, and because it destroys the work of creation. In 2008 the Norwegian Directorate of Health arranged a national conference on FGM in Trondheim and the Ministry of Culture has funded the translation of Abdinur Mohamed's treatise from Arabic to Norwegian as part of the national campaign against FGM (interview the Church March 2010). The Forum has thus supported efforts to apply fiqh in support of a cultural reform.

Both Muslims and Christians find the Forum very successful. They have reached a progressively deeper understanding of each other's religion, as the participants have become more confident to share and discuss matters. The Forum has also been represented in other dialogue groups. One of MST's members represents Norway in a European Muslim-Christian dialogue; and in 2009 the Forum went to Copenhagen to visit a dialogue group and a project with 'hospital imams' (interview MST March 2010).

When asked about the discrepancy in power between the Church and MST, MST's participants emphasize that precisely because the Church is so well established the 
dialogue has raised MST to the level of equal partner with the Church of Norway, which they see as an important sign of recognition of Islam (interview MST March 2010; dialogue meeting April 2011). One Church representative pointed out that while the Church commands the dialogue agenda through its proximity to state and public authorities, and not least proficiency in the Norwegian language, the Muslim colleagues are becoming more and more confident to contribute with their perspectives and to ensure that they are understood correctly (personal communication September 2011). MST representatives also stress that the dialogue has allayed worries among some of their members that Christian Norwegians might be hostile to Muslims (dialogue meeting April 2011). They feel that they have contributed substantially to their Christian colleagues' knowledge of Islam, and they see the willingness of Christians and Muslims to cooperate on general and specific matters that is expressed in the dialogue as a sign of increasing religious tolerance (interview MST March 2010).

The fact that the dialogue addressed issues related to the childcare authorities and the cartoon crisis is very important for MST's representatives, as it shows that the Church wants to improve Muslims' everyday life by addressing issues which are not among the state's and the public authorities' priorities (such as FGM or 'integration'). By opening doors to public institutions, the Forum has furthered MST's members' understanding of the principles which guide these institutions. MST's representatives emphasize that Islamic organizations in Oslo have not succeeded in opening a dialogue with the childcare authorities, and that it is the Church's involvement that makes the difference. They also think that Trondheim's Forum is producing better results than the European counterparts they have been in touch with. They also stress that the dialogue has provided a useful democratic method, for dialogue with the public and for managing deliberations within MST after the conflict was resolved. This has enabled new members to participate in MST's leadership, which is important progress in internal democracy (interview MST March 2010).

Another progressive measure is that one of MST's members has been employed in a two-year project as 'cultural executive' at the office for hospital chaplains at 
Trondheim's St Olav's Hospital; a similar model is tried at Ullevål University Hospital in Oslo. The project is led by the state Health Department but facilitated by the national Contact Group and the Forum, inspired by the 'hospital imams' they visited in Copenhagen. MST's member sees this as yet another sign that the Church is elevating Muslims to collegial status, not only as dialogue partners but also as professionals (interview MST November 2010).

The Church representative is very pleased that the Forum has consisted of more or less the same participants since 2003, although he remarks that MST has been unable to find women participants. It was the trust engendered by this well-established framework that ensured that the dialogue partners could find a common strategy during the cartoon crises (interview Church March 2010).

Reflecting on the dialogue's branching out from the selected themes to such concrete matters as the childcare authorities' policy, the Church representative thinks it would have been egoistic of the Church to ignore the many challenges their Muslim colleagues face in relation to public institutions. Understanding MST's members' concerns has made the Church see new and challenging sides of Norwegian society which has motivated the Church to include in its concept of pastoral care the guidance of new religions and immigrants, since the Church has long experience and much practical knowledge to convey. In the context of multicultural Norway, the Sermon on the Mount implies recognizing 'the religious other' as a brother and equal (interview Church March 2010). Against this background it is significant that, among other public authorities, the State Department for Integration and Diversity (IMDi) has responded very positively to the Forum and invited the group to its local Trondheim office (interview Church March 2010).

The Church representative has also become more aware of the inconsistencies of Norwegian immigration politics. Norwegians were happy to import labourers from Pakistan and Morocco but perceive their religion as a challenge. The Church representative thus feels it is high time to manifest that Islam is here to stay and that 
society has changed irrevocably. Building mosques is one way of manifesting the change. Another is to change the established institutions from within. For example, today Norwegian prisons and hospitals host Muslim inmates and patients who often do not have access to spiritual care. In order for imams to take on these tasks practical training needs to be provided (interview Church March 2010). The project for employment of two 'hospital imams' in Trondheim and Oslo is a pilot study to chart what kind of training is needed.

Concerning Islam as a religion, the Church representative is fascinated by the difference in Islamic and Christian approaches to scripture. He finds that his Muslim colleagues are much more bound to the scriptures and to applying their principles than the dominant Christian approach to scripture as an ethical guide rather than a set of norms. For example, he and his Christian colleagues were astonished that their Muslim colleagues hold Prophetic traditions that command stoning for homosexuality to be valid commands, but that as long as there are no witnesses to the sexual act, no crime has been committed and homosexual individuals can be tolerated. This is very different from the rights-based approach which the Church follows, according to which homosexuality is detached from scripture and perceived as a personal sexual identity with a corresponding lifestyle (interview March 2010). The example illustrates that becoming acquainted with each other's scriptures and interpretations is a fruitful way to define and understand differences between Christianity and Islam, which does not reduce Islam to Christian categories and concerns (Grung 2011; Leirvik 2011).

On the whole the Church representative thinks the dialogue has achieved more than he ever imagined. The fact that the Forum members have become real friends is also very important to him, as he had no Muslim friends prior to the dialogue.

\section{The childcare authorities}

MST's dialogue with the childcare authority is a result of the conference in 2005. According to our interviewees from MST, many of MST's members are new immigrants and do not understand the principles informing Norwegian child welfare 
services, i.e. that they protect children's rights to care and safety (see Ministry of Children, Equality and Social Inclusion 2010). Some parents perceive the concept of 'children's rights' as an assault on parents' unquestionable right to care for their children. An early attempt by the childcare authorities to come to MST and inform their members of Norwegian childcare policy had not been at all successful (personal communication 2010). At the conference in 2005 the childcare authorities received harsh criticism but they saw it as an opportunity to establish dialogue with MST and to establish Muslim foster homes, among other things. The authorities have also invited MST to lectures about FGM and about what the authorities consider deficient parental care. They also encourage new employees to contact religious organizations and use them as resources (interview childcare authority June 2010).

According to the childcare representative, many of the cases when the authorities intervene in Muslim families have to do with conflicts emerging out of different approaches to upbringing between the majority and the minority. She uses a binary anthropological model of 'Norwegian' and 'Muslim' childcare to describe the conflicts. According to this model, 'Norwegian' parents strictly control small children but as the child gets older it gains progressively more freedom. In the 'Muslim' model small children have a lot of freedom but are progressively restricted as they grow older. Conflicts between the two models can occur at puberty when non-Muslim teenagers gain more freedom while Muslim teenagers (especially girls) lose theirs. Sometimes the tension between these two value systems causes conflicts between parents and children in Muslim families and the childcare authorities intervene (interview June 2010). According to the same model there are also different views of who is responsible for a child. In the 'Muslim' model the extended family often participates in child rearing, whereas the 'Norwegian' model is individual-oriented. When parents cannot provide secure surroundings for their children, the childcare authorities assume responsibility and they do not automatically consider members of the extended family to have any special role (Child Welfare Service 2010). 
We have not conducted our own research of actual conflicts leading to intervention by the authorities and of whether the concerned Muslim families find the childcare authority's model illustrative of their problems. However, it is clear that with regard to adolescent children the model constructs a binary opposition between 'Norwegian freedom' and 'Muslim control' which is also applied in public schools in the context of national campaigns against forced marriages (hearing on forced marriages Trondheim November 2011). Recent research in public schools has found that public discourse about Muslim parents as 'control-driven' is perceived as problematic by both parents and children, and that schools need to reflect on how to achieve more constructive communication with parents (ISF 2009).

Against this background it is promising that the childcare representative finds the dialogue with MST very useful for identifying mutually acceptable solutions. Sometimes the authorities have asked MST members to help supervise Muslim families; and sometimes members of MST have asked their leaders for help in contacts with the childcare authorities. MST's members think that Muslims have learned a lot about the guidelines for the childcare authorities' work, which greatly helps their everyday life. They also feel that their knowledge as Muslims has become a valuable asset to the authority, which is among their organization's objectives. The real failure in MST's view is the case with the Muslim child who was placed with a lesbian non-Muslim couple after MST and the authorities had a mutual understanding (interview MST March 2010). The childcare representative said that her department was not involved in this case. While she can see the reasons behind the decision, she also thinks it has been destructive for the trust that the childcare authorities are trying to build with the Muslim community and she would not herself have made that decision (interview childcare authorities June 2010). Both MST and the childcare representative stress that more dialogue is needed on a regular basis since new immigrants continue to arrive in Trondheim. 


\section{The State Directorate of Integration and Diversity (IMDi)}

IMDi was established in 2006 with the objective 'to contribute to equality in living conditions and diversity through employment, integration and participation' (IMDi 2010). IMDi Trondheim seeks to cooperate with minorities' organizations to inform about their translation services; experience concerning long-term unemployment and further education; and general elections. Because participation in religious organizations is often higher than in other kinds of minority organizations, IMDi is gathering information about Trondheim's religious communities in order to improve their services and has invited the Islamic organizations to information meetings. So far only MST has responded (interview IMDi February 2010).

On one occasion MST and IMDi co-organized an event in the mosque before the general elections in 2009. MST invited a panel of local politicians and IMDi informed the audience about the importance of participating in general elections and how elections shape Norwegian society. The politicians presented their party programmes and answered questions from the audience concerning teaching of mother tongue language, freedom of speech, religious education in school, and the childcare authorities. The MST member who took the initiative to organize the political panel thinks IMDi's contributions improved MST's members' interest in the general election. Because many members are immigrants, she thinks they would benefit generally from more cooperation with IMDi (interview MST February 2010).

IMDi would like to interact more regularly and praises the political panel. To encourage further initiatives, IMDi is planning to hold annual information meetings which they hope that MST and other organizations will attend (interview IMDi February 2010).

\section{The municipality}

MST and Trondheim municipality had two meetings during 2009. MST was represented by two women members and the municipality by the mayor and her political advisor. MST's aim was to establish a contact for future cooperation and to explain Islamic principles, in the first instance concerning the need for a proper Muslim graveyard and 
for women-only sessions in municipal swimming pools. The municipality was most forthcoming (interview MST February 2010). Since then arrangements have been made for a special Muslim graveyard at Kolstad with facilities for ritual washing of the dead, ready for use in 2011 (interview MST November 2010). However, gender-segregated sessions in the city's swimming pools remain to be realized.

\section{The police}

The Trondheim police have had regular contacts with MST since 2003, as a result of the police authority's strategy to establish contacts with minorities and of initiatives from MST. In 2003 some Somali members of MST felt very uneasy about the way media was stigmatizing Somalis as criminals and they contacted the police, who helped them make sense of the statistics. It showed that while some immigrant groups are overrepresented in certain types of criminal activities, immigrants and Somalis are not on average more criminal than other citizens. This was felt as a great relief for the concerned MST members (interview Police March 2010).

The police initially contacted MST and other Islamic organizations as part of their strategy to recruit staff of minority backgrounds and to combat racism within the police force (interview Police March 2010). In 2008 a Norwegian of Somali background was murdered in a suburb of Trondheim by a man known for his racist views (TV 2 Nyhetene 2009), which caused a lot of fear in the community. The police arranged several meetings in MST's mosque, informing members about the case and criminal proceedings in Norway.

In the same year (2008) a series of robberies were committed by youths whose parents were affiliated with MST. The police, MST, and the parents met to discuss crime prevention and correction. The public approach to correction is to support the individual so that $\mathrm{s} /$ he can readjust to society as quickly as possible, while the Muslim parents in this case favoured punishment, convinced that leniency would encourage further criminal behaviour. However, the parties found ways ahead that were satisfying to all 
parties; the number of robberies was reduced by 50\% (interviews Police and MST March 2010).

In 2009 MST contacted the police to mediate in their internal conflict, as mentioned above. The parties met with the police on several occasions, and the police were asked to participate as observers in two general assemblies when new constitutions were drafted and a new steering committee elected. Commenting on this process, the police representative interviewed reflected on paragraph 2.1 of the bylaws that requires MST to abide by Norwegian law unless it violates Islam's sacred principles:

One could say that, to return briefly to the conflict about the bylaws, it is an interesting problem area: what has first priority? MST's bylaws or Norwegian law? (...) There were several different suggestions in the air, and it was very clear to me what comes first, and it was self-evident to many MST members as well, that Norwegian law comes first. But far from all agreed. So if you read the bylaws today, there is a paragraph that makes you doubt (laughs apologizingly, referring to paragraph 2.1). But there we are. My job was not to produce the new bylaws, I had to be clear about that, it was to defuse the conflict and the escalation that was about to take off, and help them create a working organization. (...) And so one has to see, there is development with time (interview Police March 2010).

The police officer also thinks reflection on similar issues is called for among the general public:

We may have a lot to learn you know, for society is getting more multinational, and then we might have to have a look at the Norwegian law, I mean, the Norwegian law obviously comes first, but there is something about the Norwegian system, we should probably have a look at it. As we are becoming more and more multinational (interview Police March 2010).

One of MST's members initially had reservations against involving the police, because many members have bad experiences of the police in their countries of origin. However, 
in the end all our interviewees agreed that the police's mediation had increased trust in the police among the members, which is important for their integration into Norwegian society (interview MST February and March 2010).

The police found the mediation both challenging and educational. It was difficult to get an overview of the conflict because there were so many people involved; some of the issues at stake were not explicitly stated; and people often shifted position. Yet, the outcomes were very satisfying: MST is a functioning organization again; the police have realized that they have much to learn from immigrants regarding solving and preventing crime; their new knowledge has challenged their established views of the law; and they have got a much more nuanced picture of Islam and Muslims. The police mediator is particularly impressed that MST manages to keep together so many different nationalities, cultures and languages (interview Police March 2010). He attributes the success to the openness and interest in others' views that he finds among MST's members, a democratic spirit he finds lacking in many other civil society organizations (dialogue meeting April 2011). These experiences have made the police realize how damaging media reporting about Muslims is. Local media covered the conflict within MST in a way that generated a lot of public suspicion, even though smaller and more homogeneous Norwegian organizations regularly have much more serious conflicts than MST but without attracting any media attention (interview Police March 2010).

\section{Concluding analysis}

This very limited study of interactions between MST, the Church and the other public institutions finds that dialogue within the normative framework of civic integration can result in two-way accommodation between 'majority' and 'minority'. This became possible in cases where the Church and the public authorities were prepared to subject their beliefs, values and policies to scrutiny by MST's Muslim members. Through the dialogues MST's members gained an enhanced understanding of the policies of public institutions which enabled them to negotiate their interests in relation to these same institutions. In accommodating MST's interests the public institutions have retained 
their principles at the same time as they accommodated Muslim values and concerns. For example, selecting Muslim foster families for Muslim children has not changed the quality criteria for approving foster families, only expanded the range of qualified families by introducing the religious category 'Muslim' in the selection. Similarly, when the police accommodated the Muslim parents' views on how to correct young delinquents they did so within the limits of national correction policy. It appears that the Church and the dialogue Forum have contributed significantly to this development. For MST's members, practising dialogue as a method to define and explain different standpoints has provided them with a democratic tool that has been very useful in contacts with the public as well as for deliberations within the organization. In particular, relations with the childcare authority were very strained prior to the Foruminitiated conference and the subsequent dialogue between MST and the authority. Moreover, the fact that the Church of Norway treats Muslims as equal partners in dialogue and increasingly also as professional partners, and publicly supports Muslims' rights to promote their interests in relation to public institutions, is perceived by MST's representatives as highly significant for their feeling of recognition as Muslim Norwegian citizens.

The significance of a 'Muslim citizenship ethics' for these developments might be important as well. MST is a member of IRN and has been more active in dialogue with public institutions than the other Islamic organizations in Trondheim. While the other organizations' members are of course just as good citizens as MST members, MST's official emphasis on 'active citizenship' aligns the organization with IRN and is also reminiscent of the Muslim Brotherhood's concept of European Muslim citizenship. Although MST as an organization cannot be identified with the Muslim Brotherhood since its members are truly diverse, its imams and leaders consult the ECFR where the FIOE's concept of European Muslim citizenship is actualized through fatwas. Furthermore, MST's 'pan-Islamic' identity makes it more suitable as public representative for all Trondheim's Muslims than the specifically Turkish Mevlana and 
the Twelver Shiite Ahl O'Bait (the fourth organization, Dar El Eman, is too recent to have any record of activities).

The question is then to what extent MST's public activities make it a 'de-privatized public Islam' in Casanova's sense. This limited study indicates that MST does not engage in a struggle to define modern boundaries. Rather, MST encourages its members to enter into dialogue with the Church and public authorities in order to actualize their civil and human rights. In other words they are working within the system, not challenging it. The results of their dialogues are thus not challenging the various institutional systems but ensuring that the systems accommodate the interests of Muslim citizens. For example, MST does not question homosexual couples' right to adoption but asks that Muslim children should be placed in Muslim foster families; the former would be to challenge the system based on religious values while the latter works within the system but seeks to protect the right of Muslim parents to confer their religion to their child (which is a human right).

When we apply Roy's concept 'churchification of Islam' to MST, a second pattern emerges. MST's leaders are assuming traditional chaplain tasks, such as spiritual care for the sick and for criminals. Planned future training programmes for Muslim leaders and imams will be modelled on training for priests and chaplains. This is to be expected given that the two religions are working within the same public institutions and thus have to relate to the same public requirements. MST's membership in IRN as the national Islamic umbrella organization has also been decisive for the Church's selection of MST as dialogue partner, and this status continues to contribute to the process of shaping national Islamic interlocutors for both the Church and the state. This means that MST as an organization is gaining more contacts with public institutions, which could be seen as a de-privatization of Islam because MST's members are seeking to make public authorities consider religious interests. On the other hand, since the Church has always worked with a range of public institutions and authorities, MST does not shift any established boundaries by following suit. 
However, 'churchification' in terms of organization and engagement with public institutions does not mean that Islam loses its distinctiveness as religion. The case of Imam Abdinur's treatise demonstrating that FGM lacks support in Islamic scriptures illustrates this point well. The treatise is an exercise in classical fiqh addressing an issue of concern for the national health and childcare authorities, and in collaboration with the same authorities. The process leading to its translation and national distribution shows two things: that the Church and Norwegian public authorities perceive Muslim scholars and Islamic scholarship as valuable resources for society; and that real two-way dialogue is necessary to raise public awareness of this fact. Trondheim, the epicentre of Norwegian national identity, and its Forum for Muslim-Christian dialogue, presents some examples of how these resources can be used wisely-which in this case means: to the satisfaction of all the involved parties, not just one side.

\section{References}

Abdinur Mohamed Mohamud, 2011: Nei! Islam avviser omskjaring av kvinner, Knut Kittelsaa forlag, Trondheim.

Amir-Moazami, Schirin, 2010: “D’égal à égal? Herméneutique critique du dialogue initié par l'État avec les musulmans d'Allemagne", Sociologie et sociétés, 42, 1: 171-196.

--- 2011: "Dialogue as Governmental Technique: Managing Gendered Islam in Germany", Feminist Review 98: 9-27.

Casanova, José, 1994: Public Religions in the Modern World, The University of Chicago Press, Chicago.

Cesari, Jocelyne, 2004: When Islam and Democracy Meet: Muslims in Europe and in the United States, Palgrave Macmillan, New York.

Dornhof, Sarah, 2012: "Rationalities of Dialogue", Current Sociology, 60, 3: 382-398.

Grung, Anne Hege, 2011: “Interreligious Dialogue: Moving between Compartmentalization and Complexity", Approaching Religion, 1: 25-32. 
Holm, Inger Marie, 2011: "Somaliere og norsk skole: en studie av somaliere i Norge med særlig fokus på relasjoner mellom lærere og foreldre”, $\mathrm{PhD}$ thesis, Faculty of Humanities, Social Sciences and Teacher Training, Tromsø University.

IMDi, 2008: “ Ungdom med innvandrerbakgrunn: Verdier, normdannelse og livsvalgen kunnskapsstatus", Monica Five Aarset, Hilde Lidén, and Idunn Seland, IMDi-rapport 10-2008.

IMDi, 2009: Annual Report 2009, "Immigrants in the Norwegian Media".

ISF, 2009: Foreldreskap og ungdoms livsvalg $i$ en migrasjonskontekst. Report by Monica Five Aarset and Miriam Latif Sandbæk. IMDi/ISF, 2009:7.

Leirvik, Oddbjørn, 2011a: "Interreligious Hermeneutics and the Ethical Critique of the Scriptures”, in David Cheetham, Ulrich Winkler, Oddbjørn Leirvik and Judith Gruber (eds.): Interreligious Hermeneutics in Pluralistic Europe: Between Texts and People, Rodopi, Amsterdam, pp. 333-352.

--- 2011b: "The Cartoon Controversy in Norway: The New Christian Right and Liberal Fundamentalism Confronting Islam?” in Ulrika Mårtensson et.al. (eds.): Fundamentalism in the Modern World. Volume 2: Fundamentalism and Communication: Culture, Media and the Public Sphere, I.B. Tauris, London, pp. 125-146.

--- 2007: Religionspluralisme i Norge: Mangfold, konflikt og dialog i Norge, Pax Forlag, Oslo.

Mårtensson, Ulrika, 2013: "Hate Speech and Dialogue in Norway: Muslims 'Speak Back"”, in Ralph Grillo and Marcel Maussen (eds.): 'Regulation of Speech in Multicultural Societies', special issue in Journal of Ethnic and Migration Studies, Vol. 40, No. 2, pp. 230-248.

Naguib, Safinaz-Amal, 2001: Mosques in Norway. The Creation and Iconography of Sacred Space, Novus forlag, Oslo.

Roald, Anne Sofie, 2002: "Religionsdialogiska perspektiv: En fallstudie av en dialoggrupp i Södra Sverige”, in Michael Stenmark and David Westerlund (eds.) Polemik eller dialog? Nutida religionspolitiska perspektiv bland kristna och muslimer, Nya Doxa, Falun, pp. 83-97. 
Roy, Oliver, 2004: Globalized Islam: The Search for a New Ummah, Columbia University Press, New York.

--- 2009: Holy Ignorance: When Religion and Culture Part Way, Columbia University Press, New York.

Verkaaik, Oskar, 2010: 'The Cachet Dilemma: Ritual and Agency in New Dutch Nationalism', in American Ethnologist 37, 1: 69-82.

Vogt, Kari, 2008: Islam på Norsk. Moskeer og islamske organisasjoner i Norge, Cappelen, Oslo.

\section{Internet}

Freedom, 2007: "Felles erklæring om Trosfrihet", 22 August 2007, at http://kirken.no/index.cfm?event=doLink\&famId=17546. Accessed 18 June 2010.

Forum, 2010: "Forum for muslimsk-kristen dialog, Trondheim: Perspektiver fra samtalen 2005-2009”, at www.menighetogmisjon.no/.../20052009\%20Perspektiver\%20på\%20dialogen-b.doc. Accessed 4 April 2011.

IMDi, 2010: at http://www.imdi.no/en/Sprak/English. Accessed 24 June 2010

IRN Bylaws, 2006: Vedtekter for Islamsk Råd Norge, at http://irn.no/2006/upload/IRN\%20vedtekter\%20vedtatt\%202006.pdf. Accessed 12 October 2010.

IRN, 2010: Published 19 August 2004, at http://www.irn.no (see Organization). Accessed 11 October 2010.

Ministry of Children, Equality and Social Inclusion, 2010: at http://www.regjeringen.no/en/dep/bld/Topics/Child-welfare.html?id=1058. Accessed 25 August 2010.

MST Bylaws, 2010: at http://www.msit.no/wpcontent/uploads/2009/09/MST_FellesForslag_VEDTEKTER.pdf. Accessed 3 April 2011. 
Samtalen 2003-2005: "Dialog mellom kristne og muslimer i Trondheim. Perspektiver fra samtalen 2003-2005", at http://www.kirken.no/nidaros/index.cfm?id=20360. Accessed 4 April 2011. STL, 2010: at http://www.trooglivssyn.no/index.cfm?id=136722. Accessed 18 June 2010.

TV 2 Nyhetene, 2009, "Nekter skyld for drap på norsk-somalier”, published 27 April 2009, at http://www.tv2nyhetene.no/innenriks/krim/nekter-skyld-for-drap-paanorsksomalier-2700002.html. Accessed 14 October 2010.

Violence, 2009: "Say NO to violence!", published 9 September 2009, at http://kirken.no/english/news.cfm?artid=265872. Accessed 2 April 2010. 